\title{
ABIOTIC AND BIOTIC FACTORS IN COAL MINE SOILS INFLUENCE ECTOMYCORRHIZAL COMPOSITION AND SYMBIOSIS ${ }^{1}$
}

\begin{abstract}
Jenise M. Bauman ${ }^{2}$, Shiv Hiremath, and Amy Santas
Abstract. Surface mining for coal leads to significant changes in ectomycorrhizal (ECM) fungal community composition by removing host plants and altering the structure and chemistry of the soil environment. These changes impact ECM fungal composition and efficiency of ectomycorrhizal formation. This study investigates the influence of soil abiotic factors on ECM community composition and root colonization. Two different surface coal mine sites in Ohio, U.S.A. were used: an abandoned surface mine and a site reclaimed under the Surface Mining and Control Act of 1977. Within the abandoned site, three unique conditions were delineated: 1) remnant forest edge, 2) restoration plots consisting of Pinus virginiana, and 3) non-vegetated sites. American chestnut (Castanea dentata Marsh. Borkh) were sown as nuts for use as ECM trap trees. The presence and identity of native ECM were determined by fungal DNA sequencing of the internal transcribed spacer (ITS) region. Relationships between fungal genera and soil characteristics were determined by a non-metric multidimensional scaling (NMDS) ordination. A multiple regression was used to determine which soil variables influenced ECM root colonization. Results illustrated significant differences between the abandoned mine soils when compared to the reclaimed soils in terms of $\mathrm{pH}$, phosphorus, and potassium. ECM fungal composition was dependent upon the levels of phosphorus, organic matter, and magnesium in the soil. Certain ECM genera were associated with higher phosphorus and $\mathrm{pH}$, while some were linked to nutrient impoverishment. Differences existed between two ectomycorrhizal fungal species within the Scleroderma genera, suggesting that not all species within a genus share environmental preferences. Organic matter was a significant predictor of ECM root colonization. Knowledge of these factors will be helpful for designing suitable mine reforestation strategies such as prediction of ECM fungi, use of ECM inoculum, and soil amendments.
\end{abstract}

Additional Keywords: anthropogenic soil disturbances; abandoned coal mines; legacy mines; soil fungi; seedling establishment; mine reclamation; Castanea dentata

${ }^{1}$ This manuscript was submitted to JASMR for consideration and was not presented at any of our meetings

2 Jenise M. Bauman, Professor, Huxley College of the Environment, Western Washington University, Poulsbo, WA, 98370; Shiv Hiremath is a Research Scientist with USDA Forest Service, Delaware, OH 43015; and Amy Santas, Professor, Department of Biology, Muskingum University, New Concord, $\mathrm{OH}$. 


\section{Introduction}

In temperate forests, approximately $90 \%$ of roots on forest trees are colonized by a diverse assembly of ectomycorrhizal (ECM) fungi (Visser, 1995). In undisturbed ecosystems, ECM diversity can be quite rich (Horton and Bruns, 2001), surpassing hundreds of species within a forest stand (Courty et al., 2008; Smith and Read, 2008). Such fungal assembly results from an integration of many abiotic and biotic factors including mineral nutrients, soil depth, $\mathrm{O}_{2}$ and $\mathrm{CO}_{2}$ concentrations, amount and quality of organic matter, temperature, moisture levels, host plants, and the age of the forest stand (Blasius and Oberwinkler, 1989; Bruns, 1995; Smith et al., 2002). How these factors interact to promote distribution of ECM species and plant interactions is not well understood (Leake, 2001; Lilleskov et al., 2004; Burke et al., 2009). More information is required to better understand how these symbiotic communities form when ecological conditions are altered by large-scale, anthropogenic disturbances (Buscot et al., 2000).

Surface mining for coal leads to significant changes in ECM community composition by removing host plants and altering the structure and chemistry of the soil environment (Jones et al., 2002; Jasper, 2007; Bauman et al., 2013). Soils left behind can be very difficult to generalize; they are largely heterogeneous with zones of high acidity (Hossner et al., 1997), patchiness of nutrients (Mummey et al., 2002), metals, and organic matter (Boruvka and Kozak, 2001). These differences in the soil structure and chemistry may influence the ECM species composition and efficiency of ectomycorrhizal formation, even at small spatial scales. In addition, the removal of host plants and organic material causes a dramatic decline in fungal populations, promoting the low species richness of ECM fungal genotypes. This tends to favor the selection of a very few, yet important, fungal species that can tolerate drought (Swaty et al., 2004), persist after anthropogenic disturbances (Horton and Burns, 2001), or survive in soils with toxic levels of metals and temperature extremes (Samson and Fortin, 1986; Iordache et al., 2009).

To enhance tree seedlings' ability to absorb water and nutrients and tolerate heavy metals and low pH, ECM inoculum is commonly used in restoration (Castellano, 1996; Walker, 2004; Nara, 2005). Seedlings used in reclamation projects are either pre-inoculated with selected ECM fungi in field nurseries or in greenhouses as potted plants. Bauman et al., (2011) reported that seedlings out-planted on a reclaimed mine site did not maintain their original ECM inoculum. 
Regardless, the fact that seedlings were colonized prior to planting contributed significantly to the survival of the seedlings within the first few months. Further, subsequent root colonization by certain native ECM fungi improved chestnut seedling growth within the first two seasons (Bauman et al., 2011). Documenting fungal genera that correlate with abiotic soil conditions may contribute to our understanding of how ECM communities reassemble during soil recovery in areas that have been severely degraded (Jasper, 2007). Knowledge of these factors may provide a sense of predictability of these fungi and aid in management decisions when approaching a reforestation project. A better understanding of ECM fungal response to secondary soil disturbances during restoration may also aid in determining whether inoculum is needed, or whether spores or existing mycelium provide propagules for root colonization (Fox, 1986; Deacon and Fleming, 1992; Bauman et al., 2012). Certain environments may contain species or genotypes of organisms that can better survive human-caused environmental stresses (Gerhing et al., 1998) and better facilitate the establishment of native plant species.

The objective of this study was to use environmental soil data such as $\mathrm{pH}$, soil nutrients, and organic matter to determine the influence of soil environment on ECM community composition and root colonization. American chestnut (Castanea dentata) was used as a trap tree to sample ECM in the field due to its affiliation with ECM genera in both forested and reclamation soils (Palmer et al., 2008; Bauman et al., 2013). Two different surface coal mine sites in Ohio, U.S.A. were used, an abandoned surface mine and a site reclaimed under the Surface Mining and Control Act (SMCRA). Within the abandoned surface mine site, three unique conditions were delineated and experimentally replicated: 1) remnant forest edge, 2) restoration plots consisting of Pinus virginiana, and 3) non-vegetated sites. This was compared to a fourth site that was reclaimed under SMCRA, which included the addition of stockpiled topsoil, mechanical grading, and seeding with non-native species that resulted in an exotic grassland. This study investigated how variations in the abiotic characteristics of the soil environment influence ECM community composition and the effect of differences in soil chemistry and organic matter on ECM root colonization. The overall goal of this study was to improve our knowledge of how abiotic soil variables influence plant/fungal interactions, which can be taken into consideration when approaching the restoration of disturbed landscapes. 


\section{Methods and Materials}

Site description and soil sampling:

Two different mines were sampled for ECM fungi. The first is an abandoned coal mine located in Avondale Wildlife Area in Muskingum County, Ohio (39 49' 44" N, 82 $2^{\circ} 7^{\prime} 38^{\prime \prime}$ W; Fig. 1A). This site is within an abandoned mine representative of surface mined sites prior to the Surface Mining Control and Reclamation Act of 1977 (SMCRA) in Ohio. This site was mined in the 1950s and has had very little reclamation aside from experimental tree plantings resulting in small monoculture pine stands (Pinus virginiana). Soil quality is poor and is comprised of abandoned gob and mining debris. The site is characterized by less than $5 \%$ vegetative cover and poorly sorted debris. There is no topsoil, very little organic matter, and presumably low microbial activity. This area receives an average of approximately $99 \mathrm{~cm}$ of precipitation annually with temperatures averaging $22^{\circ} \mathrm{C}$ during the growing season $\left(17^{\circ}, 28^{\circ}\right.$, and $11^{\circ} \mathrm{C}$, spring, summer, and fall, respectively; National Climatic Data Center). Within this site, three distinct areas were sampled: non-vegetated sites, 10-year-old pines that were able to establish in areas adjacent to the non-vegetated sites, and edges of forests that were a product of natural recovery in areas around the perimeter of the abandoned site.

To provide for blocking and replication within this abandoned mine site, the site was divided into three blocks of 0.80 ha (Bauman et al., 2012). Each block contained 6 plots $(4 \mathrm{~m} \times 3 \mathrm{~m})$ belonging to each habitat type: forest edge (near the edges), non-vegetated sites (away from edges), and 10-year-old pine plots that were in the vicinity of 10-year-old Pinus virginiana. Soil characteristics in each habitat type resembled those found in abandoned gob piles (soil mixed with coal debris; Fig. 1). Forest edge plots were placed 4 meters from the edge of the forest canopy spaced $10 \mathrm{~m}$ from each other. The areas designated as center plots were completely devoid of trees and were located in the center of the field site, approximately 25 meters from the forest edge. The $P$. virginiana in this area were established as bare-root seedlings in the spring of 1997. These pines averaged 2 to $2.5 \mathrm{~m}$ in height with $1 \mathrm{~m}$ spread in 2007 . These plantings were located about 50 meters from the forest edge and were designated as pine habitat.

The second coal mine was located in Tri-Valley Wildlife Management Area, Muskingum County, Ohio (40 11' 32" N, 81 $98^{\circ} 35^{\prime \prime} \mathrm{W}$; Fig. 1B) and reclaimed under SMCRA in the 1980s. This reclaimed mine is typical of post-SMCRA sites (McCarthy et al., 2008) and is

primarily vegetated with the original species used for reclamation (Festuca spp. and 
Lespedeza spp.). These areas were sampled as "grasslands". This area receives an average of approximately $99 \mathrm{~cm}$ of precipitation annually. During the 2007 and 2008 growing seasons, the summer climate was relatively dry to moderate drought, with annual temperatures averaging $22^{\circ} \mathrm{C}$ during the growing season $\left(17^{\circ}, 28^{\circ}\right.$, and $11^{\circ} \mathrm{C}$, spring, summer, and fall, respectively; National Climatic Data Center).

Pure American chestnut seeds (Castanea dentata Marsh. Borkh), provided by the American Chestnut Foundation, Meadowview, VA, were planted in the spring of 2007 and sampled at the end of the 2008 growing season. The abandoned mine located in the Avondale Wildlife Area had three distinct areas from which samples were collected. Although 18 plots (six plots in three blocks) were initiated per mine area within the abandoned mine, not all plots had surviving seedlings. Therefore, we were able to sample from six non-vegetated plots, six plots along the forest edge, and 10 pine plots. Each plot was $4 \mathrm{~m} \times 3 \mathrm{~m}$ and each $4 \mathrm{~m} \times 3 \mathrm{~m}$ plot was considered as one sample to avoid pseudo-replication. Six, $4 \mathrm{~m} \times 3 \mathrm{~m}$ grassland sites were sampled from TriValley Wildlife Management Area. Additional preparation was required for planting chestnut seeds in the grassland plots. This included cross-ripping soil at a depth of approximately 1 meter by a D-6 dozer with a $1.0 \mathrm{~m}$ steel ripper bar attachment followed by a plow and disk using a conventional tractor (McCarthy et al., 2008).

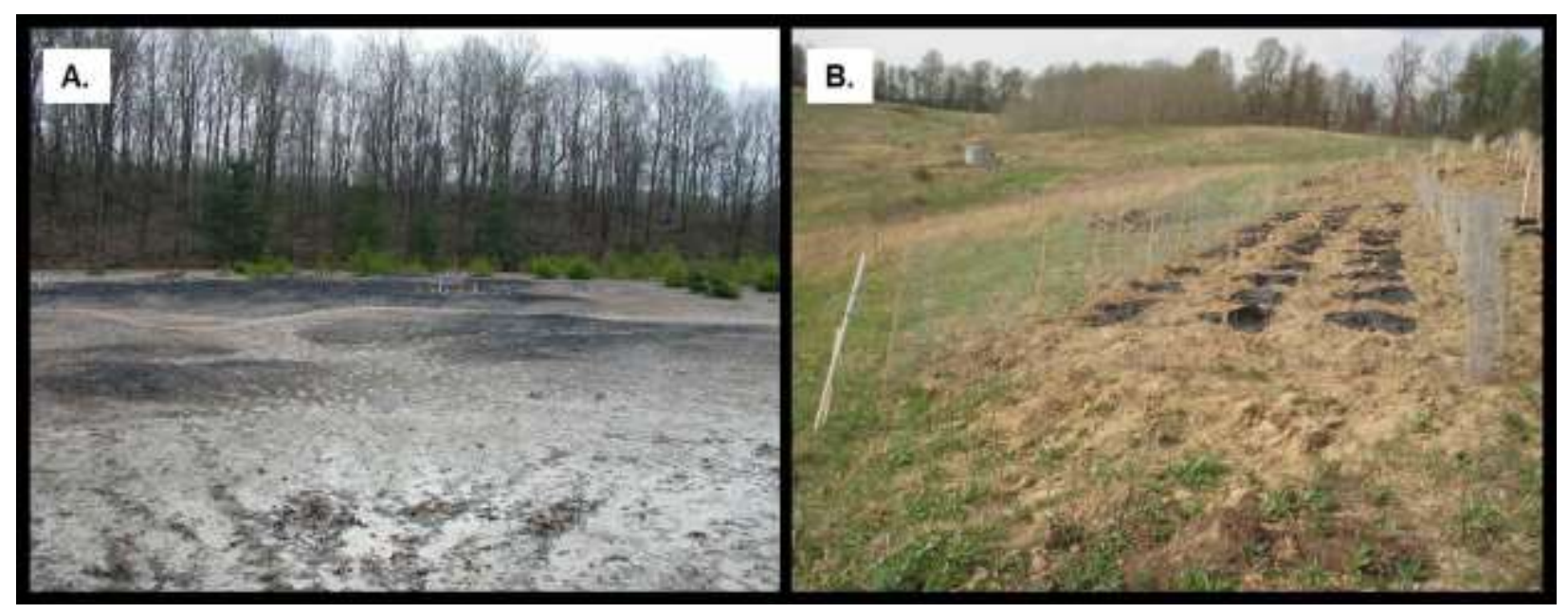

Figure 1. Two different mines were sampled for ECM fungi. Panel A shows the abandoned coal mine located in Avondale Wildlife Area, location of the non-vegetated, forest edge, and 10-year-old pine plots. Panel B Tri-Valley Wildlife Management Area, location of the grassland treatment.

In the fall of 2008, two harvest dates retrieved 129 surviving seedlings, representing all sample plots: 48 grassland seedlings, 21 seedlings from forested edge, 27 seedlings planted in 
non-vegetated plots, and 33 seedlings planted in the pine plots. Seedlings were carefully removed from the field, stored on ice, and returned to the laboratory within 24 hours. In the laboratory, the entire root system was washed using distilled water, roots were cut into $3 \mathrm{~cm}$ segments, and stored in Petri dishes at $4^{\circ} \mathrm{C}$ for 7 days. All samples were observed under a dissecting microscope for ectomycorrhizal formation determined by the presence of a fungal sheath. One hundred root tips per seedling were randomly selected from root segments. Using a grid template as a guide, the number of ECM root tips was divided by the total number of roots sampled up to 100 tips to calculate percent ECM. ECM was morphotyped based on the color and texture of sheath, emanating hyphae, and presence of rhizomorphs (Nara et al., 2003). Morphotypes were counted and used for the subsequent multivariate analysis (described below). Two samples per morphotype per seedling were selected for DNA extraction. A three mm segment of root tip was removed and transferred into a microcentifuge tube and stored at $-70^{\circ} \mathrm{C}$ until extraction.

Soil samples were collected from a depth of $0-18 \mathrm{~cm}$ using a soil probe from both Tri-Valley and Avondale Wildlife Areas, four samples per plot. The four samples per plot were mixed thoroughly, allowed to air dry, and 0.50 liters were sent to Spectrum Analytic Inc., Washington Court House, Ohio for analysis. Soil variables measured were: $\mathrm{pH}$, soil texture, organic matter, $\mathrm{P}, \mathrm{K}, \mathrm{Mg}, \mathrm{Ca}$, cation exchange capacity (CEC), Al, S, Bo, $\mathrm{Zn}, \mathrm{Fe}, \mathrm{Cu}$, and $\mathrm{Mn}$. All macro and micronutrients were measured using the Mehlich 3 extraction method.

\section{DNA extraction and purification:}

ECM present on root tips were identified by DNA extraction followed by PCR of the ITS fingerprint region and DNA sequencing (Hiremath and Lehtoma, 2007). Two samples per morphotype, per seedling, were selected for DNA extraction. As mentioned above, a $3 \mathrm{~mm}$ segment of root tip was removed, transferred to a microcentrifuge tube, and stored at $-70^{\circ} \mathrm{C}$ to

await DNA extraction. Briefly, the $3 \mathrm{~mm}$ segment was homogenized using a bead beater, and DNA was extracted using QIAgen's DNeasy Plant Mini Kit per manufacturer's protocol. About $10 \mathrm{ng}$ of this DNA was used in PCR reactions using primers ITS1-F (5' cttggtcatttagaggaagtaa 3') and ITS4 (5' tectcegcttattgatatgc 3'), which amplify the highly variable internal transcribed spacer (ITS) region of ECM fungal ribosomal DNA (rDNA) (Gardes and Bruns, 1993). PCR $15 \mu \mathrm{l}$ reactions were mixed based on the following concentrations: $9 \mu \mathrm{l}$ of molecular grade water, $3 \mu \mathrm{l}$ of $5 \mathrm{x}$ Green GoTaq ${ }^{\circledR}$ Reaction Buffer, $0.125 \mu 1$ of Promega ${ }^{\circledR}$ Taq DNA Polermerase, $.2 \mu 1$ 
of $25 \mu \mathrm{M}$ of each primer, $1 \mu \mathrm{l}$ of dNTPS $(200 \mu \mathrm{M}$ each of dATP, dCTP, dGTP, and dTTp), and 1 $\mu \mathrm{l}$ of DNA template. Temperature cycling was accomplished using a programmable Thermal Cycler Heating block. Times and temperatures were programmed as described by Gardes and Bruns (1993): The initial denaturation step was $94{ }^{\circ} \mathrm{C}$ for $85 \mathrm{~s}$ followed by 35 amplification cycles of denaturation, annealing, and extension. The temperature and times for the first 13 cycles were $95^{\circ} \mathrm{C}$ for $35 \mathrm{~s}, 55^{\circ} \mathrm{C}$ for $55 \mathrm{~s}$, and $72{ }^{\circ} \mathrm{C}$ for $45 \mathrm{~s}$. Cycles $14-26$ and 27-35 repeated the above parameters with lengthened extension steps 120 and $180 \mathrm{~s}$, respectively. When the 35 cycles were completed the samples were programmed to incubate for $10 \mathrm{~min}$ at $72{ }^{\circ} \mathrm{C}$ for $45 \mathrm{~s}$.

After confirmation using gel electrophoresis, the PCR products were purified using Wizard ${ }^{\circledR}$ SV 96 Genomic DNA Purification System (Promega, USA) and used for DNA sequencing. Sanger sequencing was performed with The Applied Biosystem ABI Prism 3730 DNA Analyzer (Bioinformatics Facility, Miami University, Oxford, Ohio). The DNA sequences were analysed and edited using the Sequencher 4.2 software (Gene Codes, Ann Arbor, Michigan). To identify the fungi found on roots to genus, ITS sequences from samples were compared with those in GenBank using the Basic Local Alignment Search Tool (BLAST; Altschul et al., 1997). From 129 seedlings, 205 ECM root tips were sampled, which produced 151 sequences. Of the 151 sequences, 97 matched $>95 \%$ to our previously GenBank published accessions (Bauman et al., 2012; Bauman et al., 2013). The remaining 54 sequences matched other fungi that represented similar genera. To be conservative, we only reported the 97 sequences that did match $>95 \%$ of the database. Therefore, authors acknowledge that other genera may have been sampled but lacked the similarity match to be considered additional genera reported in this paper.

\section{$\underline{\text { Statistical analyses: }}$}

Principal component analysis (PCA) was used to extract the initial set of uncorrelated components from the independent soil variables sampled from Tri-Valley and Avondale Wildlife areas. To avoid redundancy in correlated variables, autocorrelated variables were removed before PCA was performed. Linearity and normal distribution assumptions were met by transforming $(\log 10+1)$ and standardizing (Wisconsin double standardization) the dataset. An eigenvalue threshold of unity (1.0) was used to retain factors in the model. Eigenvalues are the sum of squared correlation between the original independent variables and the principle components obtained, and they represent the amount of variance attributable to the components. Each of the components were rotated to facilitate their interpretation, and then referred to as 
factors. An orthogonal rotation (Varimax rotation) was used in this analysis to obtain the factors, maintaining their independence. Factor loadings were used to interpret the resulting factors. Absolute loading value $>0.75$ was used to interpret the resulting factor pattern.

Differences in soil chemistry among the sampled plots were identified using a multivariate analysis of variance (MANOVA) followed by ANOVAs. MANOVA significance was evaluated using Wilks' $\lambda$ test statistic. Description of ECM per site was quantified by species richness based on fungal genera, Shannon-Weiner diversity index, and Simpson's index of diversity based on ECM tip counts for each morphotype. ECM colonization per treatment was assessed by taking the percentage (\#ECM tips/100) of ECM colonized root tips from chestnuts planted as bare root seedlings. When significant, an ANOVA followed by Tukey's HSD post hoc was used to assess differences among sites. PCA, ANOVAs, and MANOVAs were performed using JMP (8.0, SAS Institute, Cary NC, USA).

A non-metric multidimensional scaling (NMDS) ordination was used to determine if ECM community composition, quantified by root tips counts on American chestnut, differed among the four sites (metaMDS function in vegan package, version 2.13.0). To improve the NMDS ordinations, the data were square root transformed and standardized via Wisconsin double standardization (Oksanen. 2005). Bray-Curtis dissimilarities were employed due to their preferred analysis for community data due to the restriction within the range of 1 to 0 (Kindt and Coe 2005). The maximum number of random starts in search was set at 100 with $\mathrm{k}=2$ stress value. A permutational multivariate analysis of variance (formerly nonparametric MANOVA) was used to test for significant differences among the soil treatments using the adonis function in vegan package, version 2.13.0. This is a method for partitioning variation in dissimilarity or distance matrices using a "pseudo-F" statistic analogous to MANOVA (Oksanen et al., 2005). All ECM community statistics were performed using Vegan: Community Ecology Package.

To determine whether ECM fungi were correlated with the soil measurements, environmental variables were fit onto the NMDS fungal genera ordination via fitted vectors. These vectors are shown as the strength and direction of the correlations between the ordination and environmental variables (Oksanen et al., 2005). This was accomplished by employing function envfit to the ordination. This results in directional cosines of the vectors along with the squared correlation 
coefficient $\left(\mathrm{r}^{2}\right)$. The significances are presented by a p-value based on random permutations of the data.

A multiple regression analysis was used to determine which independent variable best predicted percent ECM root colonization. To meet model assumption of normality and equal variance, predictor variables were transformed $\log 10+1$ and standardized, and the dependent variable (ECM \% root coverage) was arcsine transformed. The optimal number of variables to include in the models was determined by choosing the best subset regression with the lowest Bayesian information criterion (BIC) using R (version 2.13.0).

\section{$\underline{\text { Results }}$}

Since there were many soil factors (variables) in our study, we used a principal component analysis (PCA) and a factor analysis to identify a smaller set of correlative factors that represent the highest amount of variability. Further, we applied a varimax rotation analysis to this data which provides a new set of factors that explain variances observed. Table 1 reports the varimax rotated factor loadings for soil characteristics of the four mine sites. Three factors contributed to a total of $78 \%$ variance. Out of these, factor 1 , contributing to $32 \%$ of the total variance, presented high loadings for $\mathrm{pH}$ and phosphorous. Factor 2 contributing $27 \%$ of variance presented high negative loadings for organic matter $(\%)$ while showing high positive loading for potassium (K). The factor 3 contributing only $19 \%$ of the total variance had high loading for manganese and high negative loading for magnesium.

Table 1. A principal component analysis (PCA) was used to identify a smaller set of factors that represent the highest amount of variability. High factor loadings, representing greatest variability are shown in bold.

\begin{tabular}{llll}
\hline Soil Variable & Factor 1 & Factor 2 & Factor 3 \\
\hline Soil pH & $\mathbf{0 . 9 6}$ & -0.03 & -0.26 \\
Organic Matter (\%) & -0.05 & $\mathbf{- 0 . 8 8}$ & -0.11 \\
Manganese (ppm) & -0.11 & -0.12 & $\mathbf{0 . 7 6}$ \\
Phosphorus (ppm) & $\mathbf{0 . 9 7}$ & -0.04 & -0.07 \\
Calcium (ppm) & 0.41 & 0.60 & 0.58 \\
Potassium (ppm) & -0.27 & $\mathbf{0 . 7 8}$ & -0.30 \\
Magnesium (ppm) & -0.23 & 0.06 & $\mathbf{0 . 8 0}$ \\
\hline
\end{tabular}


To further understand how these five soil characteristics (identified by the PCA) differed among the plot types, an ANOVA followed by Tukey's HSD post hoc test was used (Table 2). Soil pH $(\mathrm{F}=179.4, \mathrm{df}=3, P<0.0001)$ and phosphorus $(\mathrm{F}=20.5, \mathrm{df}=3, P<0.0001)$ were significantly higher in the grassland plots. Soil concentrations of potassium (ppm) were significantly higher in the pine plots $(\mathrm{F}=3.26$, df $=3, P=0.04)$. Organic matter $(\%)$ and manganese were fairly similar among the sites.

Table 2. An ANOVA followed by Tukey's HSD post hoc test was used on selected soil characteristics that differed among the plot types. Values in the table are the means with \pm 1 SE. Significant differences $(\mathrm{p}<0.05)$ are shown in bold text. Analyses based on data transformed by $\log _{10}+1$.

\begin{tabular}{llllll}
\hline Plots & Soil $\mathrm{pH}$ & $\mathrm{P}(\mathrm{ppm})$ & $\% \mathrm{OM}$ & $\mathrm{K}(\mathrm{ppm})$ & $\mathrm{Mn}(\mathrm{ppm})$ \\
\hline Non-vegetated & $3.0 \pm 0.1$ & $2.2 \pm 1.6$ & $1.4 \pm 0.7$ & $77.4 \pm 9.0$ & $6.4 \pm 1.1$ \\
Forest Edge & $3.0 \pm 0.1$ & $1.0 \pm 0$ & $1.9 \pm 0.5$ & $83.8 \pm 10.1$ & $6.0 \pm 1.6$ \\
Grassland & $\mathbf{5 . 3} \pm \mathbf{0 . 1}$ & $\mathbf{7 . 8} \pm \mathbf{1 . 9}$ & $1.5 \pm 0.1$ & $86.7 \pm 7.1$ & $\mathbf{3 . 8} \pm \mathbf{0 . 9}$ \\
Pines & $3.2 \pm 0.03$ & $1.5 \pm 0.8$ & $0.9 \pm 0.2$ & $\mathbf{1 1 7 . 2} \pm \mathbf{1 0 . 4}$ & $7.0 \pm 2.5$ \\
\hline
\end{tabular}

ECM Community Composition:

We identified 14 sequences that matched up to our previously published GenBank accessions. These genera included Cenococcum, Cortinarius, Hebeloma, Laccaria, Lactarius, Pisolithus, Oidiodendron, Russula, Scleroderma (sp. 1 and sp. 2), unknown ECM, Tomentella, Thelephora, and Thelephoraceae (Table 3). The more abundant genera included Scleroderma spp. 1 and 2 (44 and 21\%, respectively) and Thelephora sp. (17\%). When richness and ShannonWeiner Diversity indices were compared, no differences existed. However, differences did exist when percent colonization was compared. Seedlings planted along the forest edge $(56 \%)$ and in the grasslands (43\%) were similar and significantly greater in colonization when compared to the non-vegetated $(21 \%)$ and the pine plots $(24 \% ; \mathrm{F}=4.28, \mathrm{df}=3, P=0.02$; Table 4$)$. 
Table 3. Morphotyped ectomycorrhizal fungi (Sampled ECM) were quantified by proportion of roots colonized by ECM fungi (\%Root Colonization) and compared to the four different sites that they were sampled: grasslands, forest edges, pines, and nonvegetated plots (Sampled From) and matched to published accessions (Accession).

\begin{tabular}{|c|c|c|c|c|}
\hline Sampled ECM & $\begin{array}{l}\text { NMDS } \\
\text { code }\end{array}$ & $\begin{array}{l}\% \text { Root } \\
\text { Colonization }\end{array}$ & Sampled From & Accession \\
\hline Scleroderma sp. 1 & Scl1 & $44.50 \%$ & Grassland & GU246989 \\
\hline Scleroderma sp. 2 & $\mathrm{Scl} 2$ & $20.70 \%$ & All Sites & GU553366 \\
\hline Thelephora sp. & Thel1 & $16.80 \%$ & Non-vegetated, Grasslands, and Pines & GU553377 \\
\hline Cenococcum sp. & Cen & $3.90 \%$ & All sites & GU553373 \\
\hline Pisolithus sp. & Pis & $2.60 \%$ & Pines & GU553367 \\
\hline Thelephoraceae & Thel2 & $2.60 \%$ & Non-vegetated, Grasslands, and Pines & GU553376 \\
\hline Hebeloma sp. & Heb & $2.30 \%$ & Grassland & GU246985 \\
\hline Oidiodendron sp. & Oid & $2 \%$ & Non-vegetated and Pines & GU553367 \\
\hline Laccaria sp. & Lac & $1.20 \%$ & Forest Edge and Pines & GU246994 \\
\hline Russula sp. & Rus & $1.10 \%$ & Forest & GU553374 \\
\hline Cortinarius sp. & Cort & $<1.0 \%$ & Grassland & GU246987 \\
\hline Lactarius sp. & Lact & $<1.0 \%$ & Forest Edge & GU553369 \\
\hline unknown ECM & Unkn1 & $<1.0 \%$ & Pines & GU553372 \\
\hline Tomentella sp. & Tom & $<1.0 \%$ & Forest Edge & GU553375 \\
\hline
\end{tabular}

Table 4. Total number of genera, average richness, Shannon-Weiner diversity index, and percent colonization \pm 1 SE from chestnuts sampled among the four mine sites: non-vegetated, forest edge, grassland, and pine plots $(n=12)$. Different letters indicate significant differences by Tukey's HSD.

\begin{tabular}{lccll}
\hline Plots Sampled & Total \# of Genera & Avg Richness & Avg Diversity & \% Colonization \\
\hline Non-vegetated & 4 & $2.7 \pm 0.33^{\mathrm{a}}$ & $0.68 \pm 0.16^{\mathrm{a}}$ & $\mathbf{2 1 \pm \mathbf { 9 \% }} \mathbf{b}$ \\
Forest Edge & 7 & $3.3 \pm 1.20^{\mathrm{a}}$ & $0.78 \pm 0.40^{\mathrm{a}}$ & $\mathbf{5 6} \pm \mathbf{1 0 \%}$ \\
Grassland & 7 & $4.3 \pm 0.33^{\mathrm{a}}$ & $0.74 \pm 0.16^{\mathrm{a}}$ & $\mathbf{4 3} \pm \mathbf{1 \%}$ \\
Pines & 9 & $5.0 \pm 2.08^{\mathrm{a}}$ & $1.06 \pm 0.53^{\mathrm{a}}$ & $\mathbf{2 4} \pm \mathbf{5 \%}$
\end{tabular}

A NMDS ordination was used to illustrate how ECM fungi group in correlation with the plot types (Fig. 2). Ordination patterns illustrated a clustering of ECM communities within the two respective sites (grassland and abandoned sites). This pattern was supported by a permutational MANOVA, which showed a significant site effect $(\mathrm{F}=4.20, \mathrm{df}=3, P=0.005)$. To illustrate how soil chemistry influenced the ECM community composition, the environmental soil data ( $\mathrm{Mg}, \mathrm{Mn}, \mathrm{P}, \mathrm{pH}$, and $\mathrm{OM}$ ) were imposed as vector lines on the NMDS ordination (Fig. 2). Analysis of these correlations is presented in Table 3. Along the first dimension of the 
ordination (NMDS 1), P (ppm) correlated significantly with those fungi associated with the grasslands $\left(\mathrm{r}^{2}=0.30, P=0.03\right)$ and marginally associated with $\mathrm{Mg}\left(\mathrm{r}^{2}=0.21, P=0.08\right)$. These fungi included Scleroderma sp. 1 (Scl1), unknown ECM (Unkn1), Tomentella (Tom), and Hebeloma (Heb).

The second axis of the ordination (NMDS 2) was marginally negatively associated with organic matter $\left(\mathrm{r}^{2}=0.21, P=0.08\right.$; Fig. 2; Table 5). This correlated with ECM fungi Pisolithus (Pis), Oidiodendron (Oid), and Thelephora sp. 1 (Thel 1) that were associated with the plots among the pines. In addition, Cenococcum (Cen) appeared in the ordination with pine plots with higher pH levels. The Scleroderma sp. 2 (Scl2) and Laccaria (Lac) were associated with both pine and forest edge plots. Russula (Rus) were associated with the forest edge and were marginally influenced by the organic matter $\left(\mathrm{r}^{2}=0.21, P=0.08\right)$.

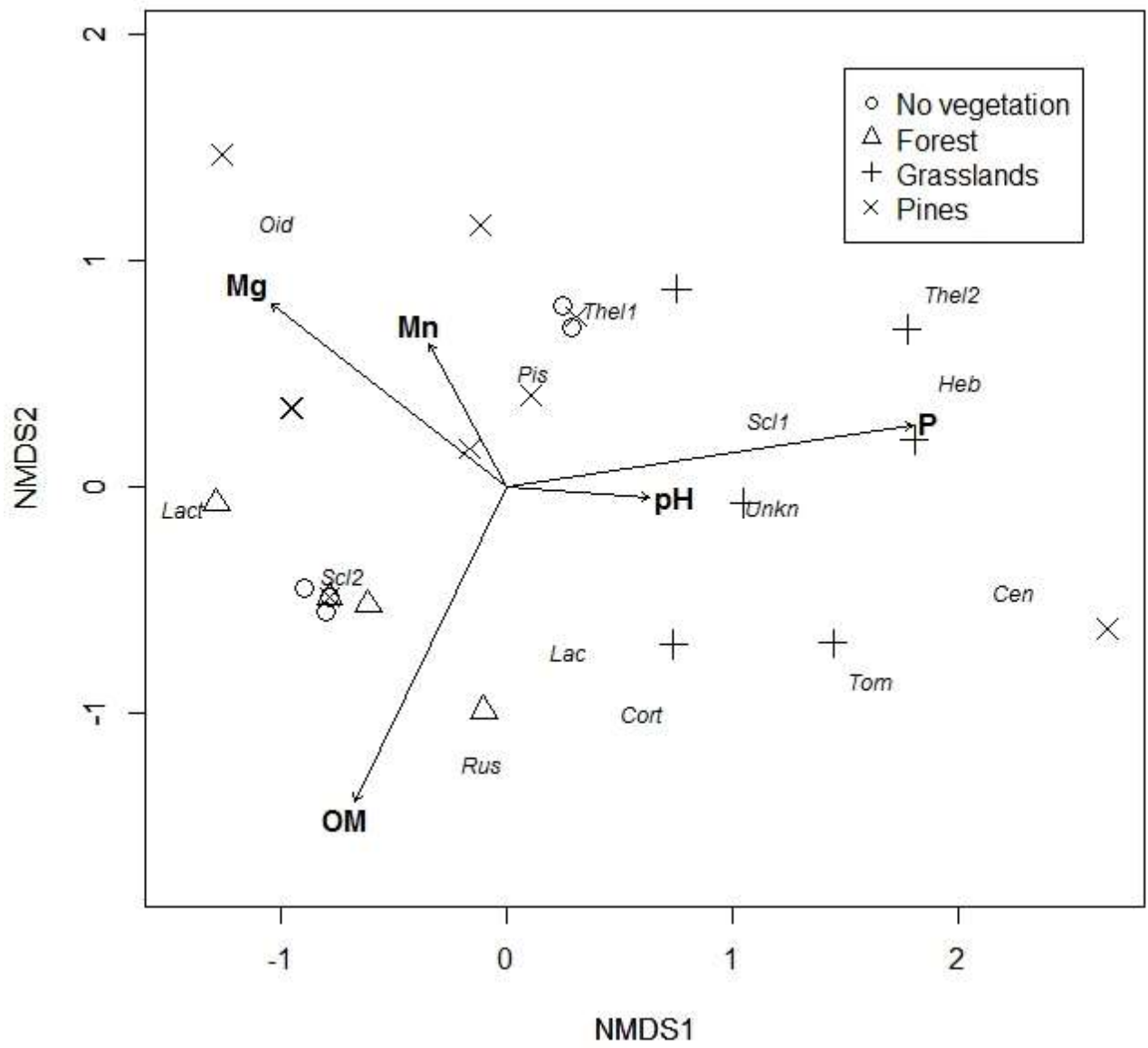

Figure 2: NMDS ordination illustrating ECM community composition (based on root tip counts) with environmental soil data $(\mathrm{Mg}, \mathrm{Mn}, \mathrm{P}, \mathrm{pH}$, and $\mathrm{OM})$ imposed as vector lines indicating strength and direction of the strongest correlations. Ordination patterns

(Caption continued on next page.) 
illustrated a clustering of two ECM community groups: 1) genera sampled from the grasslands (+) formed a distinct group and 2) the abandoned plots illustrating an overlap among the plots that represented no vegetation $(\circ)$, plots along the forest edge $(+)$, and pine plots $(\times)$. Along the NMDS 1 axis, phosphorus $(\mathrm{P})$ was correlated with those fungi associated with the grasslands and with fungi associated with magnesium $(\mathrm{Mg})$ within the pine plots. The NMDS 2 axis of the ordination was associated with organic matter $(\mathrm{OM})$ correlated with fungi within the forested plots. Fungal genera codes are listed in Table 3.

Table 5. Relationship between soil variables and NMDS dimensions of ECM community. Columns NMDS1 and NMDS2 give direction cosines of the vectors illustrated in Fig. 2. Phosphorus (ppm) correlated significantly with the first dimension of the ordination (NMDS 1). Organic matter and Mg were marginally correlated with the second dimension of the ordination (NMDS 2). Column with $r^{2}$ gives the squared correlation coefficient. The $\mathrm{P}$-values $(\operatorname{Pr}(>\mathrm{r}))$ are based on random permutations of the environmental variables as they relate to NMDS1 and NMDS2. Significant values are shown in bold.

\begin{tabular}{lllll}
\hline Soil Variables & NMDS1 & NMDS2 & $\mathrm{r}^{2}$ & $\operatorname{Pr}(>\mathrm{r})$ \\
\hline $\mathrm{pH}$ & 0.97 & -0.24 & 0.16 & 0.14 \\
Organic Matter & -0.38 & -0.93 & 0.21 & 0.08 \\
$\mathrm{~K}(\mathrm{ppm})$ & -0.56 & 0.83 & 0.01 & 0.88 \\
$\mathrm{Mn}(\mathrm{ppm})$ & -0.39 & 0.92 & 0.07 & 0.46 \\
$\mathrm{P}(\mathrm{ppm})$ & $\mathbf{0 . 9 9}$ & 0.15 & 0.30 & $\mathbf{0 . 0 3}$ \\
$\mathrm{Mg}(\mathrm{ppm})$ & -0.93 & 0.36 & 0.21 & 0.08 \\
\hline
\end{tabular}

\section{Soil Factors Related to ECM Root Colonization:}

To assess the effects of the soil variables on the percentage of ECM root tips ECM, a multiple regression was used. To find the optimal subset of predictors, the Bayes' Information Criterion (BIC) was used. The BIC identified four soil variables (organic matter, $\mathrm{Mg}, \mathrm{Mn}$, and Al) to be used in a multiple regression model. Using these variables, the regression model indicated that organic matter explained a significant amount of the variation and, therefore, could be used as a predictor of variable for $\mathrm{ECM}$ root colonization $\left(\mathrm{F}=1.91\right.$, $\mathrm{df}=39, P=0.03, \mathrm{R}^{2}=$ 0.20 ; Table 6). 
Table 6. The multiple regression related the ECM root colonization (\%) on chestnut seedlings to the soil environment. This table reports the best model selected by the BIC which included a sub-set of variables (organic matter, magnesium, manganese, and aluminum). The regression analysis shows that organic matter explained a significant amount of the variation and could be used as a predictor for ECM colonization.

\begin{tabular}{lllll}
\hline Predictor & $\boldsymbol{\beta}$ Estimate & SE & t-value & $\boldsymbol{p}$ \\
\hline Organic Matter (\%) & -7.30 & 3.30 & -2.21 & $0.03^{*}$ \\
Magnesium (ppm) & 1.81 & 3.16 & 0.58 & 0.57 \\
Manganese (ppm) & -2.09 & 3.01 & -0.69 & 0.49 \\
Aluminum (Al) & -3.31 & 2.48 & -1.33 & 0.19 \\
\hline
\end{tabular}

\section{$\underline{\text { Discussion }}$}

Our analysis of soil variables demonstrated significant differences between the two types of surface mined sites: an abandoned site with little remediation work and the site that was reclaimed under SMCRA. The grassland plots in the SMCRA-reclaimed mine site were higher in soil $\mathrm{pH}$ and $\mathrm{P}$ and lower in $\mathrm{Mn}$ than the abandoned mine site. These differences were related to the SMCRA reclamation policy that requires stockpiled topsoil to be mechanically graded back to contour and non-native cover crops to be seeded on compacted soils (Zipper et al., 2011). While SMCRA reclamation methods are critiqued for reclaiming historically forested sites into grasslands, soil characteristics are generally improved when compared to the abandoned mine lands, as seen in this study. Such reclamation has led to improved water quality, deterred soil erosion, and buffered soil pH (Davison et al., 1984), as the SMCRA policy intended. However, despite these improvements, soil conditions on reclaimed mine sites remain low in fertility, high in compaction, prone to drought conditions, and subject to invasive herbaceous species (Steiger, 1996; Bauman et al., 2015). Our study only sampled from one SMCRA site and, therefore, our results did not reflect the regional changes in the fungal species pools or illustrate variations of soil chemistry among different sites within the region (Cavender et al., 2014). In addition, soil feedbacks, influenced by parent material, age of restoration, and the reclamation vegetation can ultimately influence both soil chemistry and below-ground soil fungal communities (Dickie et al., 2006; Burke et al., 2009).

ECM genera formed strong associations with seedlings in the respective sites from which they were sampled. Fungal composition was significantly linked to the soil phosphorus content. 
Levels of organic matter and soil Mg also appeared to be potential drivers of fungal composition. These findings support the hypothesis that variations in abiotic factors influence ECM community composition. Certain ECM genera (Hebeloma, Cenococcum, Tomentella) appeared in the ordination within the grassland plots, which had higher $\mathrm{pH}$ and more availability of $\mathrm{P}$. One fungus that spatially separated from all other fungi in the ordination was the ascomycete Oidiodendron. These genera of fungus form ericoid mycorrhizas with plant species in the Ericaceae taxa (Peterson et al., 2004). Recent findings suggest these ascomycete fungi form dark septate mycorrhizas with other plant taxa (Chambers et al., 2008; Burke et al., 2009; Bauman et al., 2012). This was the case in our study where these genera formed mycorrhizas with chestnut in areas low in nutrients and high in metals, specifically associated with higher levels of Mn. In contrast, ECM fungi associated with the forest edge consisted of Russula, Laccaria, and Cortinarius. Fungi of these genera are ECM colonizers of woody trees and shrubs found in temperate forest ecosystems. Generally, these are more prevalent in undisturbed habitats (Redecker et al., 2001) and have been considered to be later-stage ECM fungi that are dominant on mature roots (Lilleskov and Bruns, 2003). Collectively, they represent fungi with long-lived clonal populations that are better competitors in undisturbed habitats having low levels of resources (Taylor and Bruns. 1999).

ECM diversity and richness were similar among the sites sampled. Percent colonization was significantly lower on sites that were non-vegetated. ECM colonization appeared to be more affected by soil organic matter, which was identified as a significant predictor of root colonization. Past studies have shown the rates and types of mycorrhizal associations to vary in response to changes in organic matter in forest systems (Baar and deVries, 1995; Dickie et al., 2006). Studies in a greenhouse, where organic matter was added to the mine soil, resulted in a significant increase in the rates of colonization by Hebeloma on Quercus seedlings (Lunt and Hedger, 2003). Furthermore, the colonization resulted in significant increase in seedling growth. Because mine reclamation operations often use the soft rock shale overburden materials in the soil substrate upon reclamation, soils are left very deficient in organic matter. In remote sites, addition of soil amendments can be logistically or economically prohibitive, and is currently not mandated under SMCRA. Instead, it would be more feasible to conserve organic matter by leaving stumps and other large organic elements in the field to aid soil fertility, improved soil structure, and ECM reservoirs (Skousen et al., 2011). 
In summary, this study demonstrated ECM community composition changes in response to selection pressures imposed by soil conditions and neighboring vegetation. The soil conditions were drivers of vegetation, which ultimately influenced resulting ECM genera that could form symbiosis under the varying soil chemistry. Within the abandoned areas, rock overburden mixed with mineral soils devoid of vegetation were similar to primary succession that selected stress tolerating ericoid fungi that could persist under nutrient and organic impoverishment. In contrast, plots adjacent to existing woody vegetation harbored ECM fungi that may exist as vegetative mycelium, able to compete under lower nutrient levels. This provides reservoirs of inoculum on existing vegetation (Bauman et al., 2012). Existing fungi can incorporate establishing seedlings into a common mycelial network, thereby facilitating their establishment in the abandoned mine sites. In contrast, the grasslands that had been reclaimed with topsoil modeled secondary succession. ECM genera can rapidly disperse into a site when restoration introduces an ECM host plant (Bauman et al., 2013). Disturbed soils may select for fungi that are high spore producers, better dispersers, and have the ability to colonize roots from spores under slightly higher nutrient levels.

\section{Acknowledgments}

This work was supported in part by a Joint Research Venture grant 06-JV-11242300-093 from the USDA Forest Service. Additional funds were provided by Research and Sponsor Programs at Western Washington University and the Glenn and Carolyn Hodges Student Research Award from Muskingum University. We thank the staff scientists from American Electric Power for assistance with site selection and materials and The American Chestnut Foundation for providing the seeds used in this study. We would like to thank Kirsten Lehtoma of the USDA Forest Service for her assistance in molecular identification.

\section{$\underline{\text { Literature Cited }}$}

Altschul, S.F. T.L Madden, A.A. Schaffer, J. Zhang, Z. Zhang, W. Miller, and D.J. Lipman. 1997. Gapped BLAST and PSIBLAST: A new generation of protein database search programs. Nucleic Acids Research 25: 3389-3402. https://doi.org/10.1093/nar/25.17.3389

Baar, J., and F. deVries, 1995. Effects of manipulation of litter and humus layers on ectomycorrhizal colonization potential in Scots pine stands of different age. Mycorrhiza. 5: 267-272. https://doi.org/10.1007/BF00204960 
Bauman, J.M., C. Cochran, J. Chapman, and K. Gilland. 2015. Plant community development following restoration treatments on a legacy reclaimed mine site. Ecological Engineering. 83: 521-528. https://doi.org/10.1016/j.ecoleng.2015.06.023

Bauman, J.M., C.H. Keiffer, S. Hiremath, and B.C. McCarthy. 2013. Soil preparation methods promoting ectomycorrhizal colonization and American chestnut (Castanea dentata) establishment in coal mine restoration. Journal of Applied Ecology. 50: 721729. https://doi.org/10.1111/1365-2664.12070

Bauman, J.M., C.H Keiffer, and S. Hiremath. 2012. Facilitation of American chestnut (Castanea dentata) seedling establishment by Pinus virginiana in mine restoration. International Journal of Ecology. 2012: 1-12. https://doi.org/10.1155/2012/257326

Bauman, J.M., C.H. Keiffer, and S. Hiremath. 2011. The Influence of Inoculated and Native Ectomycorrhizal Fungi on Morphology, Physiology and Survival of American Chestnut. Pages 16-37 In: Barnhisel, R.I., (ed.). The American Society of Mining and Reclamation Proceedings. Sciences Leading to Success. Lexington, KY. http://doi.org/10.21000/JASMR11010016

Blasius, D. and F. Oberwinkler, F. 1989. Succession of mycorrhizae: a matter of tree and stand age. Annales des Sciences Forestieres. 46 (Supplement): 758s-761s. https://doi.org/10.1051/forest:198905ART0169

Boruvka, L. and J. Kozak. 2001. Geostatistical investigation of a reclaimed dumpsite soil with emphasis on aluminum. Soil and Tillage Research. 59: 115-126. https://doi.org/10.1016/S0167-1987(01)00165-9

Bruns, T.D. 1995. Thoughts on the processes that maintain local species-diversity of Ectomycorrhizal fungi. Plant and Soil.170: 63-73. https://doi.org/10.1007/BF02183055

Burke, D.J., J.C. Lopez-Gutierrez, K.A. Smemo, and C.R. Chan. 2009. Vegetation and soil environment influence the spatial distribution of root-associated fungi in a mature beechmaple forest. Applied and Environmental Microbiology. 75: 7639-7648. https://doi.org/10.1128/AEM.01648-09

Buscot, F., J.C. Munch, J.Y. Charcosset, M. Gardes, U. Nehls, and R. Hampp, R. 2000. Recent advances in exploring physiology and biodiversity of ectomycorrhizas highlight the functioning of these symbioses in ecosystems. FEMS Microbiology Review. 24: 601-614. https://doi.org/10.1111/j.1574-6976.2000.tb00561.x 
Castellano, M.A. 1996. Outplanting performance of mycorrhizal inoculated seedlings. In, Mukerji, K. G. (ed.). Concepts in Mycorrhizal Research. Kluwer Academic Publishers B. V., The Netherlands. pp 223-301. https://doi.org/10.1007/978-94-017-1124-1_9

Cavender, N., S. Byrd, C.L Bechtoldt, and J.M. Bauman. 2014. Vegetation communities of recovering reclaimed grasslands following coal mining in southeastern Ohio. Northeastern Naturalist 21, 31-46. https://doi.org/10.1656/045.021.0104

Chambers, S.M., N.J.A Curlevski, J.W.G Cairney. 2008. Ericoid mycorrhizal fungi are common root inhabitants of non-Ericaceae plants in a south-eastern Australian sclerophyll forest. FEMS Microbiology Review.65: 263-270. $\quad$ https://doi.org/10.1111/j.1574$\underline{6941.2008 .00481 . x}$

Courty, P.E., A. Franc, J.C. Pierrat, and J. Garbaye. 2008. Temporal changes in the ectomycorrhizal community in two soil horizons of a temperate oak forest. Applied Environmental Microbiology. 74: 5792-5801. https://doi.org/10.1128/AEM.01592-08

Davidson, W.H., R.J. Hutnik, and D.E. Parr. 1984. Reforestation for mined land reclaimed in accord with public law 95-87. Journal of Environmental Quality. 1:7-12.

Deacon J.W. and L.V. Fleming. 1992. Interactions of ectomycorrhizal fungi. In: Mycorrhizal Functioning: an Integrative Plant-Fungal Process (ed. Allen MF), pp. 249-300. Chapman \& Hall, London.

Dickie, I.A., J. Oleksyn, P.B. Reich, P. Karolewski, R. Zytkowiak, A.M. Jagodzinski, and E. Turzanska. 2006. Soil modification by different tree species influences the extent of seedling ectomycorrhizal infection. Mycorrhiza.16: 73-79. https://doi.org/10.1007/s00572$\underline{005-0013-x}$

Fox, F.M. 1986. Groupings of ectomycorrhizal fungi of birch and pine, based on establishment of mycorrhizas on seedlings from spores in unsterile soils. Transactions of the British Mycological Society. 87: 371-380. https://doi.org/10.1016/S0007-1536(86)80212-1

Gardes, M. and T.D. Bruns. 1993. ITS Primers with enhanced specificity for basidiomycetes application to the identification of mycorrhizae and rusts. Molecular Ecology. 2: 113-118. https://doi.org/10.1111/j.1365-294X.1993.tb00005.x

Gehring C.A., T.C. Theimer, T.G. Whitham, and P. Keim. 1998. Ectomycorrhizal fungal community structure of pinyon pines growing in two environmental extremes. Ecology. 79:1562-1572. https://doi.org/10.1890/0012-9658(1998)079[1562:EFCSOP]2.0.CO;2 
Hiremath S.T. and K. Lehtoma. 2007. Ectomycorrhizal fungi association with the American chestnut. Proceedings of the 2006 USDA Interagency Research Forum on Gypsy Moth and other Invasive Species; 2006 January; Annapolis, MD. p 55.

Horton, T.R. and T.D. Bruns. 2001. The molecular revolution in ectomycorrhizal ecology: peeking into the black-box. Molecular Ecology.10:1855-1871. https://doi.org/10.1046/j.09621083.2001.01333.x

Hossner, L.R., H. Shahandeh, and J.A. Birkhead. 1997. The impact of acid forming materials on plant growth on reclaimed minesoil. Journal of Soil Water Conservation. 52: 118-125.

Hurbert, N.A. and C.A. Gehring. 2008. Neighboring trees affect ectomycorrhizal fungal community composition in a woodland-forest ecotone. Mycorrhiza 18:363-374. https://doi.org/10.1007/s00572-008-0185-2

Iordache, V., F. Gherghel, and E. Kothe. 2009. Assessing the effect of disturbances on ectomycorrhiza diversity. International Journal of Environmental Research and Public Health. 6: 414-432. https://doi.org/10.3390/ijerph6020414

Jasper, D.A. 2007. Beneficial soil microorganisms of the Jarrah Forest and their recovery in bauxite mine restoration in southwestern Australia. Restoration Ecology. 15: S74-S84. https://doi.org/10.1111/j.1526-100X.2007.00295.x

JMP, Version 7.0 SAS Institute Inc., Cary, NC, 1989-2004.

Jones, M.D., S.M. Hagerman, and M. Gillespie. 2002. Ectomycorrhizal colonization and richness of previously colonized, containerized Picea engelmannii does not vary across clearcuts when planted in mechanically site-prepared mounds. Canadian Journal of Forest Research. 32: 1425-1433. https://doi.org/10.1139/x02-069

Kindt, R. and R. Coe. 2005. Tree diversity analysis. World Agroforestry Centre (ICRAF), Niirobi.

Leake, J.R. 2001. Is diversity of ectomycorrhizal fungi important for ecosystem function? New Phytologist. 152: 1-3. https://doi.org/10.1046/i.0028-646X.2001.00249.X

Lilleskov, E.A. and T.D. Bruns. 2003. Root colonization dynamics of two ectomycorrhizal fungi of contrasting life history strategies are mediated by addition of organic nutrient patches. New Phytologist.159: 141-151. https://doi.org/10.1046/..1469-8137.2003.00794.x 
Lilleskov, E.A., T.D. Bruns. T.R. Horton, D.L. Taylor and P. Grogan. 2004. Detection of forest stand-level spatial structure in ectomycorrhizal fungal communities. FEMS Microbiology Ecology.49:319-332. https://doi.org/10.1016/j.femsec.2004.04.004

Lunt, P.H. and J.N. Hedger. 2003. Effects of organic enrichment of mine spoil on growth and nutrient uptake in oak seedlings inoculated with selected ectomycorrhizal fungi. Restoration Ecology. 11: 125-130. https://doi.org/10.1046/j.1526-100X.2003.09968.x

McCarthy, B.C., J.M. Bauman, and C.H. Keiffer. 2008. Mine reclamation strategies for the Restoration of American chestnut (Castanea dentata). Ecological Restoration. 26: 292-294. https://doi.org/10.3368/er.26.4.292

Mummey, D., P.D. Stahl, and J.S. Buye. 2002. Soil microbiological and physicochemical properties 20 years after surface mine reclamation: comparative spatial analysis of reclaimed and undisturbed ecosystems. Soil Biology and Biochemistry 34:1717-1725. http://doi.org/10.1016/S0038-0717(02)00158-X

Nara, K. 2005. Ectomycorrhizal networks and seedling establishment during early primary succession. New Phytologist. 169: 169-178. https://doi.org/10.1111/j.1469-8137.2005.01545.x

Nara, K., H. Nakaya, B. Wu, Z. Zhou, and T. Hogetsu. 2003. Underground primary succession of ectomycorrhizal fungi in a volcanic desert on Mount Fuji. New Phytologist, 159: 743756. ttps://doi.org/10.1046/j.1469-8137.2003.00844.x

Oksanen, J., R. Kindt, and R.B. O’Hara. 2005. Vegan: Community Ecology Package version 1.6.9. http://cc.oulu.fi/ jarioksa/.

Palmer, J.M., D.L. Lindner, and T.J. Volk. 2008. Ectomycorrhizal characterization of an American chestnut (Castanea dentata)-dominated community in Western Wisconsin. Mycorrhiza. 19: 27-36. https://doi.org/10.1007/s00572-008-0200-7

Perry, D.A., H. Margolis, C. Choquette., R. Molina, and J.M. Trappe. 1989. Ectomycorrhizal mediation of competition between coniferous tree species. New Phytologist. 112: 501-511. https://doi.org/10.1111/j.1469-8137.1989.tb00344.x

Peterson R.L., H.B. Massicotte, and L.H., Melville. 2004. Mycorrhizas: Anatomy and Cell Biology. CABI publishing. Wallingford, Oxon UK.

Redecker, D., T.M. Szaro, R.J. Bowman, and T.D. Bruns. 2001. Small genets of Lactarius xanthogalactus, Russula cremoricolor and Amanita francheti in late-stage ectomycorrhizal 
successions. Molecular Ecology. 10: 1025-1034. https://doi.org/10.1046/j.1365294X.2001.01230.x

Samson, J. and J.A. Fortin. 1986. Ectomycorrhizal fungi of Larix laricina (Du Roi) K. Koch and the inter- and intraspecific variation in response to temperature. Canadian Journal of Botany. 64: 3020-3028. https://doi.org/10.1139/b86-399

Skousen, J., C. Zipper, J. Burger, P. Angel, and C. Barton. 2011. Selecting topsoil substitutes for forestry mine soils. Pages 591-609. In: Barnhisel, R.I., (ed.). The American Society of Mining and Reclamation Proceedings. Sciences Leading to Success. Lexington, KY. https://doi.org/10.21000/JASMR11010591

SMCRA. 1977. Surface Mining Control and Reclamation Act, Public Law 95-87. 30 U.S.C. $\S \S 1234-1328$.

Smith, J., R. Molina, M.M.P. Huso, D.L. Luoma, D. McKay, M.A. Castellano, T. Lebel, and Y. Valachovic. 2002. Species richness, abundance, and composition of hypogeous and epigeous ectomycorrhizal fungal sporocarps in young, rotation-age, and old-growth stands of Douglas-fir (Pseudotsuga menziesii) in the Cascade Range of Oregon, USA. Canadian Journal of Botany. 80: 186-204. https://doi.org/10.1139/b02-003

Smith, S.E. and D.J. Read. 2008. Mycorrhizal Symbiosis, $3^{\text {rd }}$ Edition. San Diego, CA, USA: Academic Press.

Steiger, J.R. 1996. Soil Survey of Muskingum County, Ohio. United States Department of Agriculture - Natural Resources Conservation Service.

Swaty, R.L,.R.J. Deckert, T.G. Whitman, and C.A. Gehring. 2004. Ectomycorrhizal abundance and community composition shifts with drought: predictions from tree rings. Ecology. 85: 1072-1084. https://doi.org/10.1890/03-0224

Taylor, D.L. and T.D. Bruns. 1999. Community structure of ectomycorrhizal fungi in a Pinus muricata forest: minimal overlap between the mature forest and resistant propagule communities. Molecular Ecology. 8: 1837-1850. https://doi.org/10.1046/j.1365294x.1999.00773.x

Visser, S. 1995. Ectomycorrhizal fungal succession in jack pine stands following wildfire. New Phytologist.129: 389-401. https://doi.org/10.1111/j.1469-8137.1995.tb04309.x

Walker, R. F., S.B. McLaughlin, and D.C. West. 2004. Establishment of sweet birch on surface mine spoil as influenced by mycorrhizal inoculation and fertility. Restoration Ecology. 12: 8-19. https://doi.org/10.1111/j.1061-2971.2004.00255.x 
Journal American Society of Mining and Reclamation, 2019 Vol.8, No.1

Zipper, C.E., J.A. Burger, J.G. Skousen, P.N. Angel, C. Barton, V. Davis, and J.A. Franklin. 2011. Restoring forests and associated ecosystem services on Appalachian coal surface mines. Environmental Management 47: 751-765. https://doi.org/10.1007/s00267-011-9670-z 